\title{
Block Batik from Natural Material of Soil on Fabric Dyes
}

\author{
Mohd Azhar Samin ${ }^{1}$, Nor Azrin Ramli', Rafeah Legino² \\ ${ }^{1}$ Faculty of Art \& Design, Universiti Teknologi MARA, 40450 Shah Alam, Selangor, Malaysia \\ 2 Form giving Research Group, Faculty of Art \& Design, Universiti Teknologi MARA, 40450 Shah Alam, Selangor, Malaysia \\ azharsamin64@gmail.com, azrinramli92@gmail.com, rafeahl@uitm.edu.my \\ Tel of 1st Author: +6019-8571964
}

\begin{abstract}
Natural elements of soil are a potential medium for block batik. The local batik producers usually use synthetic dyes, which contributed pollute the environment. There is a need for more natural dye options in block batik fabric dyeing. The practices effectively reduce waste emissions. This option will support an alternative to the batik industries, which is the current issues dealing with environmental challenges that sparked this project. This study employs an experimental textile approach. This study aims to identify soil types that can be used as colourants on fabrics suitable for batik block printing. This study will introduce eco-friendly dyes to the local batik industry.
\end{abstract}

Keywords: Batick; Block; Dyes; Fabric; Natural material; Soil

eISSN: 2398-4287C 2021. The Authors. Published for AMER ABRA cE-Bs by e-International Publishing House, Ltd., UK. This is an open access article under the CC BYNC-ND license (http://creativecommons.org/licenses/by-nc-nd/4.0/). Peer-review under responsibility of AMER (Association of Malaysian Environment-Behaviour Researchers), ABRA (Association of Behavioural Researchers on Asians/Africans/Arabians) and cE-Bs (Centre for Environment-Behaviour Studies), Faculty of Architecture, Planning \& Surveying, Universiti Teknologi MARA, Malaysia.

DOI: https://doi.org/10.21834/ebpj.v6iSI5.2934

\subsection{Introduction}

The Batik work on textile materials has gained popularity among the current generations, who quickly adapted the easy-to-do method for individualising their clothing. Consequently, product diversification through batik block making with natural dye is one of the ways to create unique, attractive and versatile effects on the batik products for the ever-changing fashion market. A greater emphasis on using natural dye in the batik industry could make a valuable contribution to environmental sustainability. Natural dyes are colourant materials derived from plants or minerals. The majority of natural dyes are vegetable dye from leaves, stems, roots of flowers and seeds. Archaeologists have found evidence of textile dyeing dating back to the Neolithic period. In China, dyeing with plants and minerals has been traced for more than 5,000 years. The essential process of natural dyeing changed little over time. Typically, the dye material was placed in a pot with water, and then the fabric was then dyed and soaked in the pot, which heated and stirred until the colour was transferred. Often, natural dyes require the use of mordant to bind the dye to the textile fibres. (El-Nagar et al., 2005).

Natural dyeing techniques are also preserved by artisans in traditional cultures around the world. In the early 21 st century, the market for natural dye in the fashion industry is experiencing a resurgence (Calderin, 2009). Western consumers have become more concerned about synthetic dye's health and environmental impact in manufacturing, and there is a growing demand for products that use natural dye. The European Union, for example, has encouraged Indonesian batik cloth producers to switch to natural dyes to improve their export market in Europe (Faizal and Ali, 2011). The clay and soil are natural substances that have reddish, yellowish, brown, and blackish colours formed naturally. There is a wide range of colours found in clay and soil of different origins and history. Black, grey, red, brown in all their varying shades and intensities are found in profusion, and occasionally white, yellow and salty-blue types are encountered. The three most potent factors in determining clay and soil colour are the proportion of silica, iron, and humus that they contain. The predominance of brown and red clay and soils is due to iron and the degree of its oxidation to highly coloured compounds.

eISSN: 2398-4287@ 2021. The Authors. Published for AMER ABRA cE-Bs by e-International Publishing House, Ltd., UK. This is an open access article under the CC BYNC-ND license (http://creativecommons.org/licenses/by-nc-nd/4.0/). Peer-review under responsibility of AMER (Association of Malaysian Environment-Behaviour Researchers), ABRA (Association of Behavioural Researchers on Asians/Africans/Arabians) and cE-Bs (Centre for Environment-Behaviour Studies), Faculty of Architecture, Planning \& Surveying, Universiti Teknologi MARA, Malaysia.

DOI: https://doi.org/10.21834/ebpj.v6iSl5.2934 


\subsection{Literature Review}

The review is based on the related studies for this project. According to Purwowidodo (1991), soil colour is derived from the transition of various types of mixed particles to give colour to the soil content. Red soil samples also show high oxidation content on iron content; more iron content causes reddish-brown soil. A land with a specific colour can be used as a natural dye. The clay and soil are natural substances that have reddish, yellowish, brown, and blackish colours formed naturally. There is a wide range of colours found in clay and soil of different origins and history. Black, grey, red, brown in all their varying shades and intensities are found in profusion, and occasionally white, yellow and salty-blue types are encountered. The three most potent factors in determining clay and soil colour are the proportion of silica, iron, and humus that they contain. The predominance of brown and red clay and soil is due to iron and the degree of its oxidation to highly coloured compounds. The alumina, lime, and vinegar were the materials that bond between dye and fibres that can be used as a soil colouriser. Most of the soil types recognised by surveyors fall into categories according to their colour.

The red soil is the more prevalent in the tropics, but the black ones are widely distributed, especially in low lying situations. The red, highly oxidised soil is formed in conditions of good drainage and correspondingly adequate aeration. On the other hand, the black soil is the product of anaerobic conditions where drainage is impeded (Russanti, 2017). The extraction of the colour component from local soil material is essential in the dyeing of any textile substrate to maximise the colour yield. Moreover, standardising the extraction process and optimising the extraction variables are both for a particular source in natural dye material. It has technical and commercial importance on colour yield and of the extraction process as well as dyeing process. Natural dye is typically taken from various plant sources from leaves, stems, roots of flowers, seeds, and mineral sources. The colour component presented in these sources needs to be extracted so that it can be applied suitably on textiles. Nowadays, industrial methods are available for removing colour components/purified colour substances from natural dyes for their accessible applications.

The extraction of the colour component from local soil material is an essential step in the dye of any textile substrate to maximise the colour yield. Moreover, standardisation of the extraction process and optimising the extraction variables are both for a particular source in natural dye material; it has technical and commercial importance on colour yield and of the reaction process as well as dyeing process. Natural dye is typically taken from various plant sources from leaves, stems, roots of flowers, seeds, and mineral sources. The colour component presented in these sources needs to be extracted so that it can be applied suitably on textiles. Nowadays, industrial methods are available for removing colour components/purified colour substances from natural dyes for their accessible applications. The textile industry currently uses large quantities of chemical or synthetic dye to colour products in different market areas, compared with natural shade. The demand is relatively minor and for niche areas (Khandegar and Saroha, 2013; Sinha et al., 2012). This outcome is linked to the fact that synthetic dyes are more economical, have superior colour fastness, wider colour variety, and have more excellent reproducibility (Bulut and Akar, 2012; Leitner et al., 2012). However, some of the dyes will create toxic that adversely affect the aquatic ecosystem. They contain mutagenic, carcinogenic and toxicological properties. And, despite the low incidence, some are associated with contact dermatitis (Bulut and Akar, 2012; Malinauskiene et al., 2012; Shahid and Mohammad, 2013; Sinha et al., 2012).

As an alternative new dye design and synthesis, it can replace the synthetic dye either derived from toxic precursors or prone to forming poisonous metabolites. The return of natural dye has increasingly been contemplated because of its biodegradability, low incidence of allergic reactions, and low toxicity (Komboonchoo and Bechtold, 2009; Mirjalili et al., 2011; Shahid and Mohammad, 2013). This approach is aligned with the growing movement in our society towards sustainability, green and environmentally friendly products, in addition to government intervention in favour of reducing environmental issues (Bechtold et al., 2007; Rossi, et al., 2017). The environmentalists are constantly worried about chemicals used in the textile industry to cause water pollution and water disposal problems (Siva, 2007; (Ali, 2011). A significant issue related to the batik industry is the discharge of wastewater produced during the soaking, boiling, and rinsing steps without proper treatment. This problem involves large volumes of water and chemicals such as synthetic and sustains with a chemical element (Aruma, 2008; Ghoreishi and Haghighi, 2003; Khalik et al., 2015). The presence of various chemicals in the effluents could threaten aquatic organisms due to their toxicities and non-biodegradability (Carmen and Daniela, 2012; Forgacs et al., 2004; Syuhadah and Rohasliney, 2011). Industry wastes cause a negatively impacts on the environment. The release of chemical dye into the atmosphere during and after making batik is a significant pollution source. Each waste treatment through physical, biological, or chemical methods are often costly (Rashidi, Sulaiman, \& Hashim, 2012). This problem is crucial as it is the backbone of the study on the colouring from local soil by using the batik block process. This research aims to identify the types of local soils that have the potential to be produced as a dye. The study also analysed the colouring effects resulting from the local grounds using various kinds of fabric. It is also used to apply and propose the outcome as a dye for block batik products.

\subsection{Methodology}

The study conducted a comprehensive review of the textile design studio process in creativity, material and technique for block batik products. The researcher explores the method of block batik colouration before selecting the type of soil that can be used as dyes. The practice-based approach deal with the textile design experimental approach. Examples can be seen below in Table 1.

Table 1: Potential Soil for Fabric Dyes

\begin{tabular}{|l|c|c|c|}
\hline \multicolumn{1}{|c|}{ Soil Types } & Soil Picture & Fabrics Used & $\begin{array}{c}\text { Dye Fixer } \\
\text { (Lime Stone Mordant Paste) }\end{array}$ \\
\hline Terracotta Soil & & Rayon & \\
& & Cotton Drill & \\
& & & \\
& & & \\
\hline
\end{tabular}




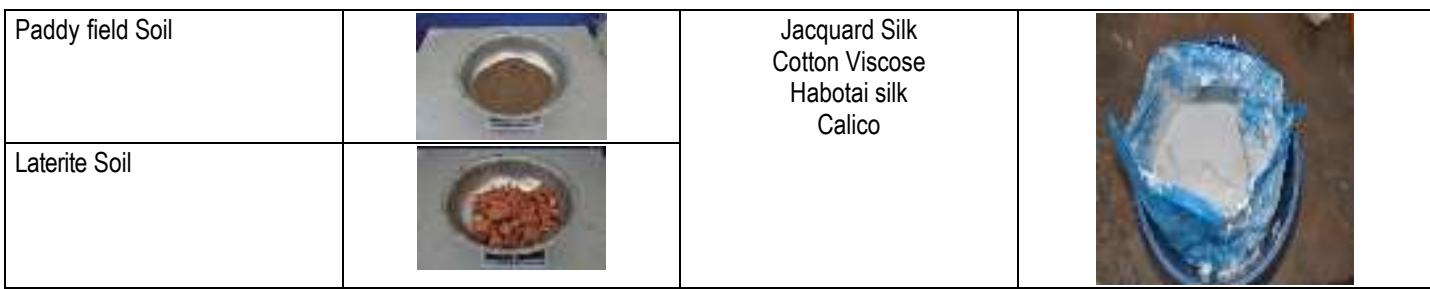

(Source: Nor Azrin Ramli (2017) Master Coursework Project Report, Faculty Art and Design, Universiti Teknologi MARA)

This study focuses on analysing the colouration of block batik using natural dyes from local soil. In this research, all the necessary tools were prepared for all the processes: block batik process, stamping process, dyeing process, fixing method, boiling process, rinsing process, and finishing process. All the procedures were conducted in a textile studio and workshop. The process involved and manages to identify the colouration effect on the different types of fabric. It is also working to identify the type of soil suitable for the block batik product. In addition, this research is also carried out to find the most appropriate colouration substance on fabric. After the colouring process, the fabric samples were fixed using limestone liquid. This research had identified a suitable medium for the natural colouration method. The textile practice base method was conducted to collect the result. The potential colouration from laterite, soil from paddy field and terracotta clay are prominent as a fabric dye. The quick dyeing process and outcome showed in Table 2.

Table 2: Dyeing Process and Outcome

\begin{tabular}{|c|c|c|c|}
\hline $\begin{array}{c}\text { Soil } \\
\text { (Natural Material) }\end{array}$ & $\begin{array}{c}\text { Natural Dyes } \\
\text { (Colouration) }\end{array}$ & $\begin{array}{c}\text { Fixer } \\
\text { (Lime Stone Liquid) }\end{array}$ & $\begin{array}{c}\text { Dyed Block Batik Fabric } \\
\text { (Dyeing Outcome) }\end{array}$ \\
\hline & & & \\
\hline & & & \\
\hline & & & \\
\hline
\end{tabular}

(Source: Nor Azrin Ramli (2017) Master Coursework Project Report, Faculty Art and Design, Universiti Teknologi MARA)

\subsection{Results}

The different soil content types will generate different colours depending on the level of substances contained in the sources. Based on the outcome resulting of the natural colouration has its own identity and can provide added value to the production of block batik. In addition, the advantages of using natural dyes derived from soil to reduce environmental pollution, accessible and cost of production are lower than the synthetic colours. Thus, promoting natural shade and the explorative research on the medium without chemicals should be advised, so the potential of Malaysian block batik products could be enhanced following the current stage. This research is beneficial in terms of the usage of natural materials as Batik Blok cloth colouration. The study aims to diversify the natural colouring properties of minerals such as soil. Soil has the potential to be fabric staining if scientific studies are conducted. The use of soil can give a unique look and value-added to block batik production. It can also improve block batik making because of the colour produced, fascinates collectors and users, who requisite naturally produced material. This study has its advantages in terms of the use of chemicalfree materials.

\subsection{Conclusion}

To sum up, this study provides a new approach in the textile industry in innovation undertaken on staining using natural dye of local soil colouration. Scientific and detailed studies need to be carried out to perceive the potential of producing batik fabrics using this natural dye. The use of mineral colouration in the industry is still none. Batik production naturally needs to be diversified to provide added value 
in producing a high-quality product. People now prefer material produced with natural elements as it is said to have a higher aesthetic value. The production of block batik using soil can protect the environment from the pollution that can affect the ecosystem. Studying the colouration of natural materials gives consumers a choice between products made from raw materials or chemicals. The diversity of fabric staining methods can allow batik entrepreneurs to enhance the efficiency of their block batik production.

\section{Acknowledgements}

The authors would like to acknowledge the Research Management Center (RMC), Universiti Teknologi MARA, for funding under the grants of the 600-IRMI/FRGS 5/3 (443/2019) for this publication.

\section{References}

Ali, S. (2011). Working capital management and the profitability of the manufacturing sector: A case study of Pakistan's textile industry. The Lahore Journal of Economics, 16(2), 141.

Arumai Dhas, J.P. (2008). Removal of Cod and Colour from Textile Wastewater Using Limestone and Activated Carbon. Universiti Sains Malaysia.

Bechtold, T., Mahmud-Ali, A., \& Mussak, R. (2007). Natural dyes for textile dyeing: A comparison of methods to assess the quality of Canadian goldenrod plant material. Dyes and Pigments, 75(2), 287-293.

Bulut, M. O., \& Akar, E. (2012). Ecological dyeing with some plant pulps on woollen yarn and cationised cotton fabric. Journal of Cleaner Production, 32, 1-9.

Calderin, J. (2009). Form, Fit, Fashion: All the Details Fashion Designers Need to Know But Can Never Find. Rockport Publishers.

El-Nagar, K., Sanad, S. H., Mohamed, A. S., \& Ramadan, A. (2005). Mechanical properties and stability to light exposure for dyed Egyptian cotton fabrics with natural and synthetic dyes. Polymer-Plastics Technology and Engineering, 44(7), 1269-1279.

Faizal, Ali Burhani (October 29, 2011). "Indonesia told to produce more 'green' products". The Jakarta Post. Retrieved November $9,2011$.

Ghoreishi, S.M., Haghighi, R. (2003). Chemical catalytic reaction and biological oxidation for treatment of non-biodegradable textile effluent. Chem. Eng. J. 95,163e169. decoration of fabrics. Courier Corporation.

Khandegar, V., \& Saroha, A. K. (2013). Electrocoagulation for the treatment of textile industry effluent-a review. Journal of environmental management, $128,949-963$.

Khalik, W.F., Ho, L.-N., Ong, S.-A., Wong, Y.-S., Yusoff, N.A., Ridwan, F. (2015).

Decolorisation and mineralisation of batik wastewater through solar photocatalytic process. Sains Malays. 44, $607 e 612$.

Komboonchoo, S., \& Bechtold, T. (2009). Natural dyeing of wool and hair with indigo carmine (Cl Natural Blue 2), a renewable resource based blue dye. Journal of Cleaner Production, 17(16), 1487-1493.

Malinauskiene, L., Zimerson, E., Bruze, M., Ryberg, K., \& Isaksson, M. (2012). Are allergenic disperse dyes used for dyeing textiles?. Contact Dermatitis, 67(3), 141 -148.

Purwowidodo. (1991). Gatra Tanah Dalam Pembangunan Hutan Tanaman. IPB Press. Bogor.

Rashidi, H. R., Sulaiman, N. N., \& Hashim, N. A. (2012). Batik industry synthetic wastewater treatment using nanofiltration membrane. Procedia Engineering, 44, 20102012.

Russanti, I. (2017). Pengaruh Jenis Mordan dan Teknik Mordanting Terhadap Hasil Jadi Batik dengan Pewarnaan Alami Tanah Merah Tuban. Jurnal Tata Busana, 6(3).

Shahid, M., \& Mohammad, F. (2013). Perspectives for natural product based agents derived from industrial plants in textile applications-a review. Journal of cleaner production, $57,2-18$.

Siva, R. (2007). Status of natural dyes and dye-yielding plants in India. Current science, 916- 925. 